\title{
Northern Affairs in 1724
}

\begin{abstract}
ALIED with Prussia under his treaty of Charlottenburg and A successful in dissuading France from concluding a separate alliance with Russia, ${ }^{1}$ George I at the beginning of the year 1724 had reason to be satisfied with his position in northern Europe. But the satisfaction was seriously disturbed towards the end of March by news of a treaty concluded between Russia and Sweden on $22 \mathrm{February}(0.8),.{ }^{2}$ which, though in its main clauses inoffensive, carried a sting in its tail. A secret article, which was not kept secret, obliged the parties to employ their strongest offices at the Danish and other courts to obtain for the duke of HolsteinGottorp restitution of his share of Sleswick, and, if they failed, to take counsel with the other powers interested, and particularly with the emperor, how this dispute might be ended satisfactorily and the danger to the peace of the north arising from it be removed.
\end{abstract}

The treaty was the result of Peter the Great's threats of the previous summer, combined with the refusal of George I, under the restraint of his British government, to render Sweden help against him. ${ }^{3}$ At first the Swedes had required that Great Britain should bo a party, and to that end had tendered their mediation for a reconciliation between George $I$ and Peter the Great; they had in view, in fact, a quadruple alliance between Russia, Sweden, Great Britain, and France. On George's part, in reply, was demanded as an indispensable preliminary a declaration on Peter's part that he was ready to forget the past, and it was stated that the only matter really requiring accommodation was the expulaion of Michael Bestuzher from London in 1720, an incident for whose cause it was the king of England's right to claim satisfaction, but which he was willing to consign to oblivion." This same Bestuzher was now the taar's minister

Ante, xxvi. 305-7 and xxrii. 71-6.

- Dumont, VII. ii. 76. A copy in the original German-the language, anys reaident Jackson, 'now used in all transactions between these two Nations' - with his dispatch of 15 Aprl (o.18.), Record Offlco, Sweden 33 : tranglations (varions), with those of Finoh and Jeakeon of March and April, ibid. 33, 34.

Ante, xrvii. 61, 67.

- Townahand to Finch, from Henover, 26 August 1723, Reoord Office, Foraign Entry Book 155 and Regencies 4. 
in Sweden, and he was believed to be anxious to forward the reconciliation, in order that he might return to London. William Finch had written on the subject from Stockholm :

I shall by this acquaint your Lordship that the King of Sweden is informed of the project of an alliance with the Czar and is not displeased with it, but on the contrary very well inclined to it, provided the King be included as a principal party. I do not perceive that the King [of Sweden] has been forced into this project by the Holstein faction, or that His Majesty and the Secret Committee came into it for any other reason than to keep the Crar quiet and themselves free from apprehension of being invaded, which they believe they shall do by such an alliance, provided the King be included as a principal party.

Recounting conversations with Count Horn, whom he was specially instructed to consult and for whose eye very complimentary dispatches were written in French, Finch stated that Bestuzher had spoken of a reconciliation, so he learnt, in terms which he could not have used without permission, and that Horn undertook to procure an address from the riksdag to the king, praying that no alliance should be made without inclusion of the king of England. "Townshend replied that this was entirely approved, and that, if friendship with the tsar were ro-established, the king would rather soo Bestuzher back in England than any other minister, he being personally most agreeable.?

But the negotiations did not proceed as was desired. To summarize the dispatches briefly, it was found that the Swedish plenipotentiaries appointed to treat with Bestuzhev were instructed only to offer their master's mediation, not to make the inclusion of the king of England in the treaty a preliminary condition. Thereupon Count Horn was informed through Finch that George I did not consider his differences with the tarar of sufficient weight to merit mediation, and Finch himself was told privately :

It is impossible the King should think of consenting to entrust any of his affairs in the hands of the Swedes ; their Government is so weak and divided, and the Czar has so great an influence among them, that they could not but be the worst Mediators we could pick out, if we wanted any. ${ }^{3}$

\footnotetext{
- Finch, 28 Angust (0.2), Rocord Office, 8weden 32, and further to like offect 11 September (o.s.).

- 'His Majesty rou'd bave you leave no stone unturned to carry the point of the Address. . . Such an Address would be both honourable and adrantageous to His Majesty, and must mortify the Cyar in a very tender part, to that after all the noise he has made, and the alarms he has given, he is so farr from keeping the Kingdom of Bweden in awe, that they will prescribe their own terms in case he is deairous of making an alliance with them.'

Townshend to Finch, 23 Septamber, Record Office, Bareign Entry Book 155.

- The same, 28 October.
} 
And though later Finch wrote of assurance that in a onunterproject handed in to Bestuzhev there was nothing in the least disagreeable to King George, who would always be distinguished as the prince most friendly to Sweden, even though, for its repose and tranquillity, steps must be taken to satisfy the tear's doubts, yet at the end of the year he had to report that, having learnt from their minister at Hanover that their mediation would not be accepted, the Swedes were disposed to obstruct a reconoiliation in any other way. He was instructed in reply to let the Swedish ministers know that the king of England would not take the ' least step that is derogatory to his honour to bring about a reconciliation with the Czar '.10 And 80 the negotiations dropped, and the separate treaty was proceeded with.

That the duke of Holstein-Grottorp should have Sleswick back the Swedes naturally desired. But against Peter the Great's demand, that he should be declared successor to the throne, they stood out. Bestuzhev, advancing the proposition, was answered that, while the affection of the nation towards the duke might support his hopes, if he conducted himself well, the present form of government must be maintained and full liberty of election must be preserved. And when he and Bassewitz, the duke's minister, presented a formal memorial on the subject, ministers, says Finch, were not a litile pleased to have in their hands a document directly contravening the treaty of Nystad; their intention, indeed, would seem to have been from the first not to grant the demand, but only to get it put forward." And so in the secret article there was no mention of the succession, but only of the restitution of Sleswick.

The powers who felt themselves immediately threatened were Denmark and Prussia. But they did not combine for their defence; each hed separate recourse to George I. The Danes, indeed, could wish to be supported by the master of so fine an army and so well-filled a treasury, and Prussia, as Holm shows, in spite of dissension on certain questions, for instance on those of the Sound tolls and of East Friesland, was on the whole more friendly to Denmark than opposed to her. ${ }^{18}$ But Frederick William I was not prepared to make an alliance particularly offensive to Peter the Great and which promised no advantage to himself. With Sleswick, as shown below, he refused to be concerned.

Hated both in Sweden and in Russia, ${ }^{13}$ the Danes had watched

- Finch, 27 Norember and 19 Deoember (o.s.), Record Offoc, 8weden 32.

10 Townshend to Finch, 10 January (o.t.) 1724.

11 Finch, 19 October (o.s.) 1723.

12 Boo Holm, Danmark-Norges Historie, 1780-1814, i. $120 \mathrm{t}$.

13 Holm (L. 77) cites Westphalon on the tearitea Catherino's batrod of overgthing that wes Danish, and romarts that the taar's principal confidente, Yagushinsty and 
with anxiety Bestuzhev's negotiations, and had continued to press for treaties of alliance with George I. When at the end of 1723 Lord Glenorchy returned from a visit to Hanover, surprise was expressed that he did not bring proposals with him. He had to report that Admiral Gabel was urging his advice for alliance with the toar instead, "1 and he expressed the fear that it would be hard to keep the king of Denmark in his present good disposition unless something were done to reassure him, for he seemed resolved to secure himself in one way or the other, rather than be obliged every year to equip a fleet. ${ }^{16}$ But receiving no light he was reduced to plead that the multiplicity of business at the opening of parliament prevented attention being given to other affairs. When he said that his master's help could always be depended upon, if wanted, 'the Grand Chancellier replied that he was very well satisfied of the good intentions of his Majesty, but that it would have a much greater effect if confirm'd by a Treaty,' and he noted 'a great desire of entring into stricter measures with his Majesty'.'

When there came to Copenhagen in March not only the news of the Russo-Swedish treaty but also reports that the Swedes were arming and that all the men-of-war at Carlskrona were being got ready to join the Russian fleet equipping at Cronslot and Reval, sixteen or eighteen of the line and six frigates, the Danish envoy at Stockholm was recalled and appeal was again made to George I. But while Townshend admitted to Finch at Stockholm that the secret article, with its 'strong intimations of further more effectual measures' to be taken for the recovery of Sleswick than the mere exercise of good offices, must make the Danes believe that war upon them was intended, ${ }^{17}$ yet he was careful to minimize the danger at Copenhagen, and it was only suggested to Glenorchy that, if the Danes had any offers to make for removing the difficulties which had hitherto stood in the way of a treaty, they should send some one with them to London. ${ }^{18}$ For in the first place there was no thought in England of sending men-of-war

Ostermsn, were of like mind. A principal cause of offence, Westphelen observed, was the rafusel to match the crown prince of Denmark with the toarevne Anne.

14 'The Grand Chsnoellier tells me that Mr. Gabel takes advantege of this Tresty's not having gone on as exily as the King expected, to endenvour to parswade him to enter into messures with the Czar, telling him he may what ho is to expect from England.'

1s Glenorcby, 28 December 1723, Record Office, Denmark 4.

16 The seme, 26 Fobruary 1724, zbid. 47.

"Townshend to Finch, 24 March (0.8.), and aimilarly to Bcott at Berlin, Record Office, Foreign Entry Books 155, 63.

"To Glenorchy, 20 March (0.8.), ibid. 5. The king "wonders that it should be expected at Copenhagen that your Lordp should receivo instructions to conclude that business there, when it has etuck for this grest while chiefly upon two pointe, the one relating to the trade of his Majesty's subjects, and the other to the reciproas obligations of the treaty' (the naval surcour, that is, cf. ante, xxvii. 61, 62). 
to the Sound, and secondly heed had to be taken of French jealousy of an alliance between Great Britain and Denmark. The duke of Newcastle, who had now succeeded Lord Carteret as secretary of state for the southern province, instructed Horatio Walpole at Paris :

the King's engagements with that Crown having been entered into jointly with France, Mongr de Morville might be assured that His Maty was not about entring into further engagements with that Court, but would deferr all thoughts of that kind, at least for some time till $\mathrm{He}$ saw how the Czar would act with regard to Him.

And though he would like to concert an answer to be made to the king of Denmark, if necessery, in view of his 'daily instances', yet he 'in this as in everything else would do nothing but in concert with the Court of France'. He was glad to know that Morville thought that some expedient might be found to satiafy both the king of Denmark and the duke of Holstein-Gottorp. ${ }^{10}$ Later, when there was a report at Paris that Denmark had acceded to the treaty of Charlottenburg, Horatio Walpole gave assurance that the king was not capable of allowing such a thing after his repeated promises, and after having deferred allianoe with Denmark 'purely out of regard to the instances of the French court'.20

Turning to Prussia, we find that power not only on the worst of terms with Sweden, ${ }^{21}$ but also increasingly mistrustful of Russia, largely in consequence of the non-execution of the late Courland marriage-treaty. At the beginning of the year Frederick William I could still call the tsar his 'waarer und bester', his 'bester und sicherster' friend, assuring him that the objects of the treaty of Charlottenburg were entirely peaceful and not in the least opposed to his interest-he could not take it ill that Prussia should seek to strengthen her position by the renewal of

1 6 April (o.s.), Britinh Museum, Add. MS. 32738.

20. Walpole to Nowcastle, 21 June, ibid. 32739.

31 Diplomatic relations betwcen Prussia and Sweden had beon broken off in conequence of the arrest of the Swedish onvoy, Count Posee, in November 1723, for debt. At the ond of January 1724 Poese left Berlin without taking leave. Also there were dieputos of considerable acerbity touching trade at Wolgast and the non-fulfilment by Prusais of her obligations to Pomeranian landowners under the treaty of 1720 . The grovity of the Poase eftair is shown by an expression of James Scott: 'S'il arrive que les Ruseses et les Suédois prennent ensemble des mesures contraires a la tran. quillité du nord, Je croy que l'affaire du Comte Poseo en sera regardé comme la cause prochnine' (15 January 1724, Rocord Office, Prussis 17). Ctoorge I refueed to interfere in these disputes because, in 'Tounshend's words, 'the King hes by oxperiencec scen that remonstrances made by his Xinister [at Berlin] make but little impreseion and have no good effect ' (to Finch, 8 February (o.8.), ibid., Foroign Entry Book 155). And, ways linch of the Swodes: 'They talk very much of the King of Prussia's ill usago of tbum, and give hints, that this would not have happed, if something had not been concerted between the King, the King of Prassia, and the King of Denmark, when His Majesty was at Berlin;' a thing which be deniod positively (10 December (o.s.) 1723, ibid., Swoden 32). 
her ancient treaties with Great Britain-and asserting that there was nothing on foot with the imperial court but the 'punctation' concluded with Count Flemming ${ }^{2}$ and efforts for a reconciliation. But at the same time suspicious inquiries were made of Mardefeld at St. Petersburg about the ships equipping at Reval and about Prince Kurakin's return to Paris, a fresh evidence, it was said, of an alliance impending between France and Russia. France, Mardefeld was told, with her far-reaching and dangerous views, was in no way to be trusted, and no doubt the growing might of Prusaia was a 'Stachel im Auge' to her as well as to Austria. And his attention was called to the reports of an alliance between Russia and Sweden, a measure of which the tsar was thought, indeed, to be incapable, but which was dangerous alike to Prussia, England, and Denmark. ${ }^{23}$

When the proximate conclusion of the treaty was known Mardefeld was informed that it was believed to have in view the recovery of the former possessions of Sweden in Germany, and urgent instructions were sent him, and again a month later, to get a copy communicated. ${ }^{24}$ Then on 1 April Wallenrodt in London was ordered to ascertain the views of the British government on the subject. He in reply reported Townshend to say in strict confidence that it was not doubted that the treaty was directed against Denmark, now the prey of a thousand anxieties about it, nor that if Denmark were overcome by Sweden the latter would go further. Therefore the king of England would like to know what measures the king of Prussia would propose; he could not advise a Prussian guarantee of Sleswick to Denmark, for the French and English guarantees already given were sufficient, but only that measures should be taken to submit the affair to negotiation. Denmark was very anxious to make alliance with Great Britain, but nothing would be done in that until the king of Prussia's views were known. ${ }^{25}$ In answer Frederick William discussed the dangers of the situation at length, and emphasized their reality. ${ }^{20}$ but meanwhile Wallenrodt

- Antes Ixvii. 68.

- Resoripta to Mardefeld, 1 January to 19 February, Staatsarohiv, Berlin. In the last-named we have further: 'So lange der Tzaar lebet, halten Wir Uns genugaam versicbert, das Wir, in keiner Occasion, $\infty \mathrm{mag}$ dicelbe boschaffen seyn wie sie will, von demselben nichte, als eine sincere Freundechaft, und alles gute, Uns zu promittiren haben; kommen abar kenfftig andero Zeiten, so wird sich auch Rath dabey finden.'

" Reacripts of 28 February and 21 and 28 March, ibid.

*Wallenrodt, 14 April, ibid. Later, however, Colonel Du Bourgay, Scott's successor at Berlin, was directed to insinuate unafficially how proper a Prussian guaranteo of Blestick, as solicited by the Danish onvoy, General Lörenorn, would be. But be wes forbidden to support the request openly, becsuse the king of Prussin would certainly require some edrantage from Denmark in retarn, and the king of England would not risk his credit by being involved in the demand (Townohend to Du Bourgay, 21 July (0.8.), Rocord Office, Foreign Entry Book 53).

" Rescript to Wallenrodt, 25 April, Staatsarchiv, Berlin. 
was writing that he and Townshend agreed that the Swedish armaments reported were but a gasconade, the latter reaffirming his master 8 desire to do anything that was necessary in concert. with the king of Prussia, but aserting his own disinclination to take procipitate action in so serious a matter before receiving further light. ${ }^{27}$

Frederick William declined to share the optimism expressed. He was genuinely alarmed at the reports of arming in Sweden and Russia, as his rescripts to Mardefeld show, ${ }^{28}$ and he was still oppressed by the fear of an alliance between Russia and France, even ascribing to French underhand intrigue the present developments. Now he desired that a joint Prussian and Hanoverian corps should at once take the field, rody to oppose in arms the apprehended Swedish invasion. And he transmitted further advices of new Russian naval preparations, suggesting that France might act by offering her mediation between Russia, Sweden, and Denmark. Austria also, he thought, had a hand in the matter, but the king of England and himself, he said, were strong enough to hold their own, though they must be ready to act, if necessary, and must prevent France from taking sides with Sweden and the tsar. ${ }^{30}$

But now reports came from Sweden of a reassuring character, for instance, of statements by Count Horn 'that the true and sincere intention of the Swedish government is to keep at peace with all the world ', and that the secret article, to which Sweden was obliged to consent, should be looked upon only as words. ${ }^{31}$ And so Wallenrodt now wrote that Townshend did not expect any enterprise on the part of the Swedes this year, and that while the assembling of an army corps was assented to, if matters became serious, it was thought to be paying too great a compliment to them to show any disquietude as yet. ${ }^{32}$ And Chambrier,

Wallenrodt, 18 and 25 April, and further 5 May, ibid.

- 26 April to 20 May, ibid.

- 'Das schlimmsto boy diesem gantzen Werck ist dieses, dass die Crohn Frankreich, ohne allem Zweiffel, mit unter der docke lieget, und an allen dicsen Nordischen Aftairen in faveur des Traseren, der Crohn Schweden, und des Hertzoga von Holstein, viol theil nimbt, in dem Abschsu, dadurch sich eine solche bande im Norden zu formiren, deren Sie sich zu ihrem interesse, bey den künftigen Conjuneturen, gebrauchen, und wodurch Sio Uns, and vielleicht auch die force des Char-Heuses Braunschweig, im Roich, allo mshl in bchec halten könne ' (to Wallenrodt, 11 April, ibid.). Townshend ecoured Wallenrodt that France had no hend in the affair and only desired the preserva. tion of peace.

- Reacripts to Wallenrodt, 2 and 6 May, and similarly again 16 May, ibid.

11 Finch, 15 April (0.8.), Record Office, Sreden 34.

16 and $18 \mathrm{May}$, Staatsarchiv, Berlin. Wallenrodt expreased the wigh that the Bwedes would undertake something, for it would givo Prussia the opportunity of annexing the rest of Swedigh Pomerania, seeing that the Swedes were now in favour neither in England, nor, as he noted from utterances of his French colleague Cha vigny, in France. 
the Prussian minister at Paris, reported a like belief there, 'non obstant le désir, que la Cour de Vienne pourroit en avoir, à fin de brouiller de nouveau les affaires dans le Nord.' It was thought, he said, that the tsar's object in insisting on the secret article was to give a touch of the spur to England, in order to hasten on the reconciliation which he so much desired, as France did slso, 'parcequ'Elle ne souhaittoit point d'avoir d'sutres Alliez en Allemagne, que Vre $\mathbf{M}^{t} \dot{w}$, le Roy d'Angleterre, et le Tzar, que ce seroit la plus magnifique Alliance, que la France pourroit avoir.' 33

It seems strange to us that such real alarm of invasion should have prevailed. Power of offence on the part of Sweden was barely existent, and the bulk of Peter the Great's forces were engaged in the Caspian provinces or on the Turkish frontier. Of the 118,000 regulars, with two or three times the number of Kalmucks, Cossacks, and Tartars, which Campredon reckoned him to command, only 33,000 regulars were in the Baltio provinces. ${ }^{2}$ But eyes were directed southwards as well as to the north and east, in consequence of the special mention of the emperor in the secret article. ${ }^{35}$ St. Saphorin was reporting frequent conferences of the Russian and Swedish residents at Vienna with the arch-enemy of Great Britain and Prussia, Vice-Chancellor Schönborn, and himself and the French envoy treated with contemptuous neglect, ${ }^{36}$ and it was believed that the emperor intended to accept the invitation given and to take up the cause of the duke of Holstein-Gottorp seriously.

The relations of George I with Austria were more strained than ever. The court of Vienna would yield no point on the contentions of the south, attacks on protestant constitutional

23 Jiay, ibid.

" Campredon, 0 Fobruary, Sbornik of the Imperial Rusaian Historical Society, lii. 159.

Is A year and a half Later Stephen Poyntz, envoy at Stockholm, sounded Count Horn on the reasons for the mention. They were strange, he eaid, and he forwarded them for curiosity; but the final one was that 'the Czar would have it 80 ', and so many material alterations had boen neceesary that the Swedes were gled to let the compliment to the emperor stand (25 August (o.8.) 1725, Record Office, Swoden 38).

a St. Saphorin on 8 February (at great length) and $25 \mathrm{March}$, Rocord Office, Germany (Empiro) 52. He wroto in his vexation : 'Que faire, my Lord, avec dee gens, lesquells s'ils pensent, $\infty$ qu'ils font tris foiblement, pensent pour so former dee illusions, qui sont plus divise entr'eux qu'ils no l'ayent jamais éth, et quil ont un Maftre qui se laises toujours dévoyer de sentiments pour edoptex ceax que lo dernier qui luy parlo luy propoese. Et commo lo procbdé qu'ils ont eu envers Mons': Du Bourg et moy en no nous communiquant point le projet qu'ils avoient envoyé en France leur a on quelque manitre réussi, ils prennent le soin le plus attentif do nows déroyer de tout.' As partly the caues of this neglect he complained of bosstings on the part of the Hanoverien envoy, Count Huldenberg, that the long-ponding negotiation for the investiture of Braman and Verden wes now confided to him: "jo ne me suis que trop apperçu, que depuis lors on me regarduit icy comme n'y signifiant presque plus rien." 
rights in Germany continued, the investiture of Bremen and Verden was still withheld, and a further quarrel had arisen on the subject of the Ostend Company. On the side of Charles VI his ambassador, Count Conrad Starhemberg, had presented in October 1723 a long list of complaints, ranging from King George's attitude towards the religious disputes, alleged aspiration on his part to predominance in the empire, and his opposition to the Ostend Company, down to personal offence given to the count in the matter of customs, excise, and carriage of letters. ${ }^{37}$ And fuel had been added to the fire by the treaty of Charlottenburg.

Prussia was in like case, in spite of the formal resumption of diplomatic intercourse. Frederick William I persisted in acts of insubordination; as they were regarded at Vienna; and in his military power Charles VI saw the principal obstacle to his own sims at autocracy in the empire: as Droysen puts it, he had to capture the Prussian position first and humble that prince who aspired to be independent. ${ }^{38}$ On the other side, while Frederick William always expressed the greatest veneration for the emperor personally, his quick temper was continually being roused by decrees of the Aulic council against him, which he attributed to Austrian ill-will. $^{30}$ The part taken by Saxony in these affairs of the empire-for instance, the issue of imperial commissions to Augustus II to make execution in Tecklenburg and in East Friesland-made matters worse. The king of Poland was the man whom Frederick William most hated; his frontier lay but thirty miles from Berlin, and he was working against him even on the very tender point of the succession to Juliers and Berg. ${ }^{\infty}$ On the Saxon side the activity and impudence of Prussian recruiting officers " brought from Augustus the threst of raising

" See Townshend to Starhembery, Hanover, 5 October 1723, Recard Office, Foreign Entry Book 222.

4 Geschichte der pressosiachen Politit, Iv. ii. 367.

- Soe the letters of Frederick William to his friend General Seckendorf, employed in mediating between him and tho court of Vienna, and the latter's reparts in Förster's Friedrich Wilhelm I, Kinio ton Prewsenen, iii. 243, and L'rkundenbuch ii. On 26 Jenuary Prince Eugene had written to Seckendorf that it wat hardly posolblo to bo well with the king of Prussis if he continued ' in seiner bisherigen ausserordentlichon Botragniss und bestandigen Anstöaslichkeiten ' ( $\not b i d$. p. 6).

- Bee Bcott's dispatches of 25 April and 6 May, Record Office, Prussia 17, and Droysen, pp. 356-7. St. Saphorin wrote on 8 May: 'Il y a dojd longtèms que j'ey inarqué a Vótre Excellence que les Catholiques de l'Empire n'omettent rion pour empecher que le Roy de Pruse ne puise remplir les vues qu'on luy attribue sur leo Pair de Bergue et de Juliers, apres le mort de l'Electeur Palatine' (Rocord Offlos, Germany, Empire, 52). Erdmannedörffer obeerves that Frederick William I was as much preoccupied during his life by this ambition as was Charles VI by the Pragmatio Banotion (Deuloche Geachichte, ii. 104).

a Soo Pöllnitz, Memoires pour servir d I Histoire des quatre derniere Souverains de la Haison de Brasddebourg Royale de Pruse, ii. 139-46. Erdmsnnodorffer (ii 807) nrites of the 'bratalen Gowaltsamkeiten und listigen Kniffen' of the offlows Not less indignation was roused in Henover and other countries then in Sarony, and in 
the 'cartel', a thing which might mean serious loss to the Prussian army by desertion. ${ }^{2}$ On this head Frederick William sought to calm the court of Dresden; he sent a cordial invitation to Count Flemming to come to Berlin for friendly conferences again. But an interview, which took place, only resulted in further misunderstanding. ${ }^{\text {t3 }}$ In addition, belief in hostile intentions on the part of the emperor and the king of Poland had lately been strengthened by the report of the formation of a catholic league which should dispose of a force of 60,000 men $^{44}$ a paper array, and not one which could intimidate Prussia with her full treasury, her own larger army ready for the field, her well-stored magazines and modernized fortresses. But Frederick William did not want war unless he was forced into it.

To Austria the natural counterpoise was France, and George I now sought to obtain from the French government the same support in the north which it was faithfully rendering in the south. With this object, while at Copenhagen and Berlin, as we have wen, the cue was to allay the alarm aroused by the Russo-Swedish treaty, in order that Great Britain might not be committed to the expense of armaments, at Paris the danger was magnified. Not, care was taken to affirm, that the king of England stood in any fear of the tear ; the prosperous state of his affairs at home and the treaties made with Prussia and solicited by Denmark rendered him easy on that head; but precautions must be taken for the

Denmark a Prusaian lieutenant caught would probably have been hanged, but that it was desired to exchange him for the murderer Pretorius, who had taken refuge in Prunsis. Pretoriug was eventanlly exchanged for twelve giant recruits (Scott, 22 February; Glenorchy, 19 Febraary, 19 September, 28 Ootober : Record Office, Prussia 17, Denmark 47).

"Thus Scott on 8 April : if the court of Dresden made further demands, 'Je vois qu'icy on sera porté a soupsonner qu'elle est instigúós a cels par la cour de Vienne, qui regarde peut-Atre la levéo du cartel entre le cour de Baxe et celle-cy comme un moyon seur et pleusible pour faire diminuer le nombre des troupes prussionnes, et pour préparer le chemin pour l'exécution de desseins que sa Mfajesté Impérisle, a co que bien des geng croyent, médite en faveur de ls catholicité ou pour étendre son autaritb dans l'empire.'

4 Boott, 80 to 30 May. The interview took plece at Lucked on the Beron frontier botrreen Flemming, travelling to Aix-la-Chapelle, and the Prusaian ministers Ilgen and Ketooh. Flemming affronted Ugen by carrying off Katech to discuss a private matter spart, and an opon quarrel was with difficulty averted. Bcott says : 'Apress a'ctre chamailles un pou sur les stiaires de Tecklenburg et d'Ostfrise, comme suesi sur les prétentions de en Majenté polonaise sur les Duchez do Juliers et Berg, ile se sont esparez sans venir \& aucuno reolution, et fort peu contens Jo croy les uns des antres.' Further negotiations took ptace when Flemming came to Berlin late in July, and though Bcott's successor, Du Bourgey, cent word that all differences were 'as good as adjusted' with him, this was by no means the caso. In Jenuary 1725 the questions of East Friesland and of the cartel had become acute, and Du Bourgay then wrote that, if Flemming did no more good on a coming visit than on the lest, he had bettar stay array (13 January 1725, Record Office, Prussia 18).

4 Droyean, p. 357. The nens was forwarded to London from Berlin with an exproseion of the desire that the British court should dissuede France from joining it (Wallonrodt, 16 May, Stastsarchiv, Berlin). 
general interest of Europe and particularly for the negotiations at Cambray, "which any diversion by new disturbances in the North at this juncture would certainly give the House of Austria an opportunity of defeating.' ${ }^{45}$ Arguing the matter with the French secretary for foreign affairs, the Count de Morville, Horatio Walpole persuaded him, he says, to represent to the Swedish minister, Baron Gedda, ' in friendly but in very strong terms ... the great jealousy and umbrage' which the secret article of the treaty must give to the northern powers, and its violation of that made between Sweden and Denmark in 1720 and guaranted by Great Britain and France. Gedda, Walpole goes on, disclaimed having seen the treaty, but protested that it was defensive only and harmless. ${ }^{16}$ According to Finch, Gedda reported home that Morville had particularly inveighed against the special mention of the emperor and the omission of any reference to the king of France, in spite of what the latter had done for Sweden ; and ministers, said Finch, were seriously disquieted, some divining the pressure put upon Morville by Walpole. ${ }^{17}$

What was decided upon was to endeavour to obtain the accession of France, and incidentally that of Holland, ${ }^{\text {ts }}$ to the treaty of Charlottenburg. Walpole, opening the proposal privately to Fleury, with whom he had established very confidential relations, ${ }^{19}$ found him greatly in favour of it. But Morville opposed, alone almost, so Fleury stated, among the members of the council. At an interview with Morville Walpole set forth that, should the tsar ' contrary to all expectations return suddenly to Petersburgh with his peace with the Turks in his

4 See Newrastlo's diepatches of April, British Muscum, Add. MB. 32738.

" To Nercantle, 3 May, ibid.

4 Finch, 13 May and 3 June (o.a), Rocord Office, Swreden 34.

4 The Dutch were beiny urged to increase their military forces with a view to impressing the court of Vienns: 26 February (o.s.) to his friend Van Goalinga, Record Office, Holland 280, a volume of very interesting correspondence of Townshend with various Dutch statesmen.

- Fleury's position was stated by Horatio Walpole in September as follows. The duke of Bourbon and Morville concerted the management of foreign a ffairs beforo they were discussed in the council, and were able to send secret orders of themselves to foreign courts; but they would venture on nothing very material without the privity of the bishop of Frejus (Fleury), so long as be maintained his influence over the young king; he, however, was a very temperate man, and did not to encroach upon their authority, only 'to spoak his mind with strength and freodom upon matters of conequence as they came beforo him ' (to Newcastle, 26 September, British Museum, Add. MS. 32740). Previougly Walpole had uritten of Floury's diecouraing to him 'a series of as good reasoning and judgement and with as great a compass relating to the whole system of Europe 1 I ever heard. . . . Although his procedings are calm and soft, yet his way of thinking is ntrong and vigorous' (31 May, Add. MS. 32739). And Lord Peterborough, who came to Paris in Augast to urge enterprives against Austria of his own spirited conception, named bim as 'the eblest men con. cornod in publick affairs' ( $\theta$ September, ibid. 32740). 
pooket',, 0 and should force the free passage of the Sound or otherwise disturb the tranquillity of the north, then he was afraid he should be 'considered in England as having been amused with fair and dilatory assurances instead of settling something solid and essential that might have warded and prevented the mischief '. Some method, he urged, should be concerted 'for being in a readiness to act upon the first alarm, and I endeavoured by this means to draw from him, without mentioning it myself, his sentiments about France's entring into the Alliance concluded between his Majesty and the King of Prussia'. Morville, however, maintained that there was little cause for alarm, and objected the danger of giving offence at Vienna and so breaking up the congress of Cambray. Fleury, on the other hand, 'assured me that his sentiments concurred entirely with mine, and that as he had the same way of thinking as I had with regard to the Emperour, so he had spoke to the same effect at the Council,' and had proposed that 'preliminaries or heads' should be drawn up and signed..$^{s 1}$

Newcastle now informed Walpole of expressions used by Count Rottembourg at Cambray to the British plenipotentiaries, Lords Polwarth and Whitworth, in favour of what was proposed, not only ' for the preservation of the peace of the North and for the securing of those acquisitions of which $\mathrm{His} \mathrm{Mety}^{\text {ty }}$ is now so rightfully possest in those parts ', but also as likely to further the alliance in negotiation with Russia; in fine, to make all the northern powers court the king's friendship. To the Dutch Newcastle thought that the first proposals should come from France, with the promise to support their opposition to the Ostend Company and to have that question brought forward at Cambray ; the king, he said, would use his utmost endeavours to persuade them to comply. Yet, he concluded, if it should appear that what Rottembourg said came chiefly from himself, 'and is not much relisht where you are,' the matter must not be pressed, lest the impression should be given that the king was looking to his own advantage. ${ }^{62}$ Walpole replied that he believed that Rottembourg's utterances 'arose purely from his own true judgment with relation to the North ${ }^{\prime 6}$, and that Morville was strongly opposed to raising the question of the Ostend Company

- A prospect not at all well looked upon by George I. Ho thought, Newcastle hed written, thet France had been too hasty in promoting the peece before the tear was reconciled to him and hed ranounced all views of troubling the north, at least for the present. And he had wanted instructions to be sent to the marquis de Bonao at Constantinople 'to put such rubbe in the way' as should delay the negotiation (to H. Walpole, 6 April (0.8.), Add. MS. 32738).

"H. Walpole to Newcastle, 17 May, rbid.

17 May (o.s), ibid.

* 'Being very conversent and intelligent in those affairs; as also from his sincere dispoaition and deaire that France should act in conoert with His Majesty for presorving the tranquillity there.' 
at Cambray and still 'very cool and backward in taking the least step towards the treaty with Prussia, untill we have a final resolution from the Czar relating to a reconciliation with His Majesty '.s

The negotiations went on till August, Fleury consistently supporting Walpole's contentions, or professing to do so, and Morville maintaining the danger of a rupture at Cambray on the one hand, and of angering the tsar, before his real intentions were known, on the other. Walpole argued on the contrary that

it was plain to me that if the Czar out of pure caprice, or with no good design was resolved to keep at a distance with his Majesty, the only means to bring him to a better temper, or to prevent his fomenting any troubles, would be the accession of France to the tresty with Prussia.

He summed up : 'Upon the whole ... there is a general good intention here to act in concert with his Majesty with regard to the affairs of the North as well as of the South;' and as to the present proposal Fleury was for it, Morville against, and the duke of Bourbon 'extremely doubtfull and divided in his opinion '.5 $\mathrm{He}$ was ordered in reply to cease from further instances and to await the issue of the negotiations with Peter the Great. ${ }^{\text {se }}$ Yet on 1 September Wallenrodt could report Townshend's opinion that, once the difficulties arising from the Quadruple Allianco-that is, the negotiations at Cambraywere settled, he would be able to persuade the French government. to accede to the treaty of Charlottenburg and give a guarantee on the known point. . $^{7}$

Frederick William of Prussia was now invited to accede to the Ruaso-Swedish treaty, and apparently would have liked to do so, were it made worth his while. But no advantage, Mardefeld was told, was to be hoped for from acceptance; his master preferred to keep his hands free in regard to northern affairs, and nothing would persuade the king of England to revoke his guarantee of Sleswick to Denmark. Yet he must not decline the invitation absolutely, but thank the tsar, and say that the matter was under consideration. ${ }^{58}$ The offer and its rejection were duly imparted to George I by Wallenrodt, and pleasure was expressed in reply. It was impossible, he was told, to find an equivalent for Sleswick excepting at the hands of Denmark,

4 24 May, zbid.

4 To Nowcestle, 17 July and 9 August, Add. MS. 32739.

4 Townshend to H. Walpole, 3 August (o.8.), Add. Mis. 32740.

"Stentsarchiv, Berlin. Townehond still expected a sucoesful outcome at Cambray, writing to $\mathrm{Da}$ Bourgay at Berlin that tho main pribciples of settlement were agreed upon (14 August (0.8.), Record Offlce, Prussis 18). Tho 'bekandter punct ' was, presumably, the sucoession to Juliers and Berg.

" Rescript to Mardefeld, 22 August, Staatuarchiv, Borlin. For Frederick William's otatement of his principle, to enter into no treaty trom which he did not derive con. siderable edvantage, $\$ 00$ arte, $2 x$ vii. $54 \mathrm{n}$. 
and so the question must be postponed. until there was opportunity for its solution. But the king was entirely of the king of Prussia's opinion that, in view of the duke of Holstein-Gottorp's expectation of the crown of Sweden, it would not be good for him to be too strong on the German side of the Baltic. ${ }^{69}$

George's position in regard to Sleswick was that he would neither force the king of Denmark to find an equivalent, nor contribute to compensation himself. On the latter point he protested strongly against the Danish assertion, that under his treaty of 1715 he had agreed to pay the half of any such compensation; and this attitude, though its justice is difficult to understand, was consistently mainteined during the ensuing years. ${ }^{60}$ On the former, when complaint was made by the Danish minister at Paris of utterances on the subject by Campredon at St. Petersburg, his contention that France had no right to support the tsar in such a demand was strongly backed from London, it being pointed out that no such condition attached to the British and French guarantees given in 1720. Newcastle wrote emphatically: 'neither France nor England have any right to impose or even so nuch as recommend to Denmark their giving an equivalent for Sleswick,' to do so might stir up at Copenhagen a dangerous enmity to both crowns. ${ }^{81}$

On the Prussian side Mardefeld had been ordered at the beginning of the year to have no converse with Westphalen on Holstein affairs, for what had passed on the subject formerly was well remembered. Solov'ev says that Frederick William

- Wallenrodt, 15 September, Stantarchiv, Berlin.

- Compare the author's Ceorge I and the Northern War,pp. 70, 72. The assertion now made was that the claim was only 'founded upon a declaration made, as the words of it lead you to think, at the time of the ratification of the treaty 1715. But the King never heard any mention made of it, till tho year 1720 , when tho $K$. of Denmark mention'd it to $L^{d}$ Polwarth as a separate article to the effoct and in the menner above mention'd. If such a declaration was given, it was not only without $\mathrm{H}$. Ma's's privity or previous order, but it was neither transmitted to him, at the same time with tho ratifications of the $s^{d}$ tresty, nor at any time oince, noither has the King yet over sen any thing of it but a pretended copy without any date and signed by nobody' (Townshend to H. Walpole, 10 August (o.8.) 1724, Britiah Museum, Add. MS. 32740). The article does not appear in the counterpart of the treaty of 26 June 1715 between Denmark and Hanover preserved in the Steatsarchiv at Hanover, because it was not signed till 16 July, when the king of Denmark refused to ratify the treaty without it. At the Record Office (Treaty Papers 4) is a copy of it in German as aigned by Baron Eltz in the camp before Straleund on 16 July and ratified by George I in London on 28 July. He must have forgotten this, and of course his British ministers had nothing to do with the matter, the treaty of 1715 only concerning Hanover. For the contentions on the subject in 1728 British Museum, Add. MS. 32765, f. $563 \mathrm{f}$., where copics of the treaty are misdated 28 July.

"To H. Walpole, 21 Angust (os.), Add. MS. 32740.

- Rescript to Mardefeld, 1 January 1724, Stantarchiv, Berlin. It was remarked : - Ob aber, und was der Königliche Dánische Hoff aus Tractaten, die Er, Seiner Seite, selbst nicht gehalten, sondern dehnen Er directo zuwieder gehandelt, practendiren bönne, das wird sich zu seiner 'Zeit zeigen.' 
declared to the Russian ambassador at Berlin that he would never oppose the succession of the duke of Holstein-Gottorp in Sweden, and that he favoured the restitution of Sleswick to him, though he would not act in that matter excepting in good company ; and it is not, in dissonance with this that we find orders sent to Mardefeld in June to make the Holstein ministers understand that their mister's prospects depended upon a reconciliation between the tarar and the king of Fngland. ${ }^{\text {su }}$ In Scott's version, as Cnyphausen informed him, Mardefeld was instructed to declare that the king of Prussia would not run counter to the British and French guarantees of Sleswick to Denmark, and that the duke had best apply himself to promote the said reconciliation, which accomplished, it might not be difficult to persuade the Danes to find him a proper equivalent. ${ }^{\text {of }}$

France also refused to accede to the Russo-Swedish treaty. When Gedda, after putting off the requests of Prince Kurakin to join with him in soliciting the accession, received formal orders to desire it, Morville, so Walpole says, desired the matter to be deferred until a conclusion had been come to with Russia, and affirmed that no engagements would be entered into separately from the king of England. ${ }^{\text {et }}$

In the meantime the British court had been seriously alarmed by reports of the king of Sweden's desire to abdicate. It was feared that the consequence would be the accession of the duke of Holstein-Gottorp and the complete subjection of Sweden to the tsar, who would then be able to attack Great Britain from its ports. The abdication, Townshend wrote, would be ' of fatal consequence' to the king's affairs at the present juncture, nor could it be believed that the king of Sweden was willing to act so mean a part, and one so injurious to his honour and interest. Finch was ordered to make inquiry-strictly private, lest the king and his ministers should 'by dismal representations of their wants and necessitys' magnify their distress, in the hope of extracting un-easonable conditions-about the strength of the royal party and of the so-called 'Patriots', and what ground

- Iotoria Rossy, book I viii, ch. 2.

4 Rescripts of 3 and 6 June, Staatsarubiv, Berlin.

"Scott, 6 June, Rocord Office, Pruesia 17. Campredon pressed the same advice on the dake, as instructed, but says: "Il est convenu de cette vérité avec moi, mais comme il est entiérement déroué a la cour de Vienne, et qu'il est certain, que cette dernière le fortifie dans l'opiniâtreté de ne jamais consentir à la cesaion du Sleswig, on ne pout nullement compter sur les paroles du duc de Holstein, très mel disposé d'ailleurs pour la Frence et pour l'Angleterre. Mais comme il est sous la tutelle du Carar, il fardra bien, qu'il en pesso par tout ce que ce Prince roudra, et je ne puis pes croire, nonobstant tout ce que dessus, que le Czar veuille courir la chance d'une guerre pour sea intérbts ' (26 Msy, Sbornik, lii. 224).

4 H. Walpole to Townshend, 30 August and 22 September, British Museum, Add. IS. 32740 ; confirmed by Morville to Campredon, 7 September, Sbornik, lii. 284.

VOL. XXVII.- Yo. CVII. 
tho Holstein faction had gained since the treaty of February. ${ }^{\circ}$ And Horatio Walpole was instructed to sound the court of France on the matter, emphusizing the danger and intimating that, were the blow to fall 'at this juncture when neither the Duke nor the Czar are come to any terms of agreement with His Majesty', the last-named might be obliged 'to withdraw his attention from the affairs of the South in order to guard his own affairs from the confusion and disaster that will threaten them ', and 80 be unable to give to France the aid she might desire, in case the negotiations at Cambray fell through. He should show the French ministers, Newcastle went on, a copy of Townshend's dispatch of 22 June (o.s.), ' concerning the King's sentiments of the affairs both in the South and North,' in order to let them see ' upon what conditions alone they may expect that assistance from the King, which perhaps they may stand so much in need of '.88

Finch's reply was reassuring; the king s enemies, he said, were few in number, and the constitutionalists could never enjoy so much power under any other ruler: the reports, he thought, were purposely set on foot in order to obtain financial assistance. ${ }^{69}$ And Walpole, having busied himself with obtaining from Gedda an exact account of the disposition of each Swedish senator, advised, as the result, that the neutrals, whose leader was Count Horn, might be influenced by favours shoun to themselves or their families; that those opposed to the king might be bought, if only he had money; and that the army, clergy, and populace were thoroughly well disposed towards him. To Gedda's hint of the propriety of a supply of money he was well enough advised to turn a deaf ear..$^{30}$

These accounts, however, were distrusted, and rightly, as it soon appeared. It was determined to transfer Finch to the Hague and to send to Stockholm in his place Townshend's immediate subordinate at the foreign office, Stephen Poyntz,

- Townshend to Finch, 6 July (o.8.), Record Office, Foreign Entry Book 1 iri.

- Newcastle to H. Walpolo, enclosing a copy of the dispatch to Finch. 13 July (o.8.), British Mluseum, Add. MS. 32739. The proviso was added: 'After you have done this, the King would have you furhear for some time preasing them more upon these subjects, lest they ahould think that He stands so much in need of their assistance to reconcile him to tho Czar, that they may impose any terms upon him, in order to gain it, or that Hik Mej's' affairs are upon such a foot, that without it they would be exposed to the utmost difficulty and hazard.'

- To Townshend, 27 July (o.8.), Record Office, Sreden 34.

- H. Walpole to Newcastle, 2 August, Britinh Museum, Add. MS. 32739. Gedda's list whowed six scnutors for the king, wix neutral, of whom two were inclined towards him, and seven for the duke, a very imaginative estimate. In another dispetch, of 18 August, Walpole set forth Gedda's arguments for a subsidy from France, and his beliet that "they wdll do nothing in it here, hut as they shall find his Majesty disposed to do'; he himmelf thinking the reamon for refusal to be the fear of disobliging the tear. 
in whom confidence could be placed. ${ }^{71} \mathrm{He}$ was instructed to apply himself 'with particular care and attention' to discover the party inclinations of the several senators; 'especially to cultivate a strict friendship and intimacy with Count Horn;' to be 'very well with' the Hessian envoy, General Diemar, who was 80 much in the king's confidence ; and particularly to watch Bestuzhev,

and give constant and exact accounts of what you shall discover relating to the views and designs of the Muscovite Court, it being of the greatest importance to Our service to be well informed of all the Czar is carrying on in Sweden, that We may be the better enabled to prevent any new disturbances breaking out in the North.

In private instructions, set out in extended detail, Horn was stated to be 'the man of the greatest capacity and integrity at that Court, the best disposed towards Us and Our nation', and what Poyntz was to say and how conduct himself towards him was exactly prescribed. Whereas, it was stated, 'the main end' of sending him to Stockholm was 'to prevent the success of any attempt the Czar may make this summer for placing the Duke of Holstein on the throne of Sweden,' if his inquiries should result in finding that a sum of fifty or a hundred thousand pounds would enable the kingdom to be put in a proper state of defence, he might let it be known that such a sum could be found, in case only of an actual attempt on the part of the tear and upon condition that he himself should direct the disbursement of the money. And further he was authorized to expend in case of absolute necessity $£ 15,000$, or $£ 20,000$ at most, in 'gratifications' to the senators, but very cautiously and 'by different and distant payments', in order to keep them in a greater dependence. And, as ('ount Horn was 'strongly inclined' to favour the duke's succession, 'and as we have no reason to be against the said Duke, but what arises from his relation to, and dependence upon the Czar,' Poyntz might let it be known that, were the latter dead, or the duke out of his influence, all friendly offices could be rendered to him ; but he must do this very cautiously, lest the king should come to know of it. The instances, which the king and Diemar were sure to make immediately for a supply of money, must be repelled,

"As correctly published in the Ledtres historiques. Ixvi. 214, there was required 'un Ministre aftidé, qui soit capable de manier a vec dextérité une affaire si dólicate '. Finch could not be oummarily recalled, an had boen Sir Luke Schaub, that other of Cartoret's men, from Paris, on account of the great influence of his family ; and as the post at the Hague was higher, though now of little consequence, Newcastle was able to represent the transfer to be a mark of the king's esteem (to H. Walpole, 20 July (0.8.), Britizh Museum, Add. MS. 32739). 
but 'in so soft and gentle a manner, as not to drive them into an absolute despair as to this particular' ?

Poyntz reached Gothenburg on 2 October, and, as expected, was inmodiately approached on the king's behalf for money 'for counter-bribing the Czar "is Into his elaborate expositions of the state of parties and of individual inclinations it would be out of place to enter. ${ }^{74}$ He stated the real contest to be not between Hesian or Holsteiner for the throne, nor between adherence to Great Britain or to Russia, but whether the crown should govern or the senate. In their 'implacable jealousy' of the king, suspected of aiming at recovering the lost prerogatives of the crown, all, he said, seemed 'to look with an evil eye on any Foreign Power from whom they think he may receive the least personal support', and therefore were disposed 'to run blindfold into the interests of the Czar and the Duke of Holstein, though in their hearts they are afraid of them both'. Two or three senators at most were for the king, and, if he retained the crown, it would be principally through the jealousies and divisions of parties. As to his financial embarrassments, not only had he no money of his own, but was $£ 28,000$ in debt to General Diemar. But the British government was less disposed to send help now than ever. In January, discussing the question at length, Townshend expressed the concern of George I at the condition of Sweden and of its king, but also his conviction that the disorders arose from causes which no foreign power could remove; he blamed especially the woakness shown by Frederick I during his reign, as oausing him to forfeit all confidence at home and deterring any one abroad from helping him. ${ }^{76}$

We must now turn to the work of reconciliation between George I and Peter the Great. The ceaseless endeavours of Campredon at St. Petersburg were still defeated by the refusal of either to yield on the questions of Mecklenburg and Hölstein, although on those directly affecting Great Britain there was a disposition to agree. That George was desirous at least of giving no further offence to Peter is indicated by a special instruction to Colonel Du Bourgay, who was appointed in May to replace James Scott at Berlin, ${ }^{78}$ to converse with Count Golovkin there as freely as

71 Instructions to Poyntz, open and private, 7 September (o.8.), Record Office, Sweden 35. The ebove is but a very brief indication of the contents of the twentyfour clausty of this lengthy document.

"By the king's private secretary, 'Törne, a long private interviow with whom Poyntz. still at Gothenhurg, recounts on 30 September (o.s.). He reached Stockholm on 19 Detwber.

"Record Office, Sweden 35. One of them, of 4 November (0.s.), covers fifty-one pages of manuscript, rivalling the essays of St. Saphorin.

it 12 January (0.8.) 1725, ibid.

"Scutt's recall had been roquested in a roscript to Wallenrodt of 21 December 1723 (Staatsarchiv, Berlin), on the ground that he could not be trusted to work with 
with the other foreign ministers, and without entering into excuses for or vindication of what was past to hear his offers and report." Frederick William of Prussia, as has been noticed, was anxious for the recunciliation, partly from the natural desire that the two powers, to whom he most looked for support. should be at one, partly from his old fear of a separate alliance between Russia and France. And if one wore to be made between Great Britain, France, and Russia, he wished to be included in it. Thus Chambrier. in reply to his dispatch of 23 May cited above. was instructed that nothing could be more desirable than such a quadruple alliance, and that the king of Prussia hoped to succeed in his efforts for the reconciliation, could Campredon be ordered to act in concert with Mardefeld. ${ }^{78}$ Further dispatches from Chambrier were encouraging; they set forth Morville's sympathy with the aim expressed and his consent to send Campredon the desired orders. ${ }^{79}$ To which his master replied in his pleasure: 'Je seconderois, autant qu'il me sera possible, les intentions de la Cour de France, non seulement dans cette affaire, mais aussy dans toutes les autres qui se pourroient jamais présenter.' 80

Yet in London there was doubt in regard to the real intentions of the Prussian court. Du Bourgay was instructed :

We think fit more particularly to recommend to your care the hindring his Majesty from entring into any engagements with the Czar without consulting us beforehand. . . Whenever you shall discover any transaction of such a nature going on, you should not contradict the King in what he is doing, but skilfully disswade his Majesty from proceeding too farr without making a confidence of his views that way to Us; by shewing him how sincerely earnest We are to advance his true interests; how great an affection We have for him, and how inuch it is for the real service and advantage of his affairs to preserve inviolably the strict union of counsells and designs, which was so happily gettled between us by the late allyance.

For his behaviour at the Prussian court Du Bourgay was recommended to apply himself particularly to obtain the good opinion and confidence of the queen of Prussia, George's daughter, to cultivate intimacy with her servants, and of the king s ministers

sincerity for a good understanding between Great Britain and Prussia. Apparently his relations with the Polish court, to which he had formerly been accreditod, mado him. Inspect. In choosing Du Bourgay respoct seems to have been had to the small estimation in which Frederick William held rivilians. Others proposed, says Wallonrodt, were Lord Scarborough and General Wade, but Du Bourgay ara preferred to please the duke of Argyll (4 Angust, ibid.).

7 Townshend to Du Bourgay, 11 May (0.8.), Record Office, Foreign Entry Book 53. The order had reference to the trouble between Finch and Beatuzhev at Stockholm (below, p. 504 n. 95).

7" Rascript to Chambrier, 3 June, Staataarchiv, Berlin.

72 27 June and 1 July, ibid.

- Rescript of $22 \mathrm{July,} \mathrm{ibid.}$ 
especially with Ilgen and Cnyphausen, ' and in a more particular manner to transact Our affairs by their means and through their hands.' He was also 'to be very well' with General Grumbkow, who could be of great use to him and was so disposed to be, having broken with the prince of Anhalt ' and being thereby become ready to embrace measures more expedient for Our service'. But in this he must be very circumspect, in order not to give offence to the others, and with the prince of Anhalt and his party civil but not intimate. ${ }^{81}$

Du Bourgay arrived at Berlin on 4 July. A fortnight later, he says, the king, who had just returned from Wusterhausen, 'did me the honour to entertain me upon the methods he thought the most effectual to reconcile our Court and the Czar.' But after that other subjects held the field. Thus on 12 August : 'there is nothing talk'd of now relating to the affairs of the north,' attention being wholly devoted to the prospects of the congress of Cambray. Should a rupture between Spain and Austria take place, he was asked, what would be the king of England's attitude? To which he replied, as best he could, evasively. Complaints, too, against Hanover embarrassed him, the more annoying because they were well founded. ${ }^{83}$

About the middle of August very encouraging advices were received from Mardefeld and transmitted to Chambrier and Wallenrodt. ${ }^{84}$ But there was still distrust. Townshend, Wallenrodt reported, while desiring him to thank the king of Prussia and stating that the king of England's views upon a reconciliation were well known to the tsar, yet believed that the Russian utterances were only intended to amuse. ${ }^{85}$ And nystery still attached to Prussian engagements with Russia. ${ }^{36}$ To clear matters up the

1 Private and alditional instructions, 11 May (0.8.), Record Office, Prusola 18. The two mininters named had all along boen the principal advaranries of Georgo 1 at the Prussian court. Full particulars of their quarrel are given in Die Briefe $B \delta$ ig Priadrich Wilhelms I. an den F troten Leopold zu A nhale Dessau, text and introduction.

- 'The King of Prosaie's desire for a rupture in hopes to make an advantage is beyond what can be imagined.'

- Du Bourgay, 22 July to lis August, Record Office, Prussia 18.

4 Reocripts of 14 and 15 Augurt, Staataarchiv, Borlin. In the latter: 'Haben Wir die Nachricht von dem Russiwehon Hoffe, dass der Tzaar, jetzo, sehr portiret sey, da vorige gute Vernehmen mil dem Künige in Engeland zu retabliren.'

¿ Wallenrodt, 1 September, ibid.

a ' Since the conclusion of the Czar's with the Turks, his Pruseian Majesty heving sppear'd to be under some grest uneasineses and anxiety, the Queen was pleas'd to lot me know, that she believed it procoeded from some former engagement, that his Prussian Mejesty had contrary to his interest unwarily entre'd into with the Cear, who chalenged newly the parformance of it, which his Pruseian Mejesty would gladly shifft off.' This, Du Bourgey went on, was in ecordanoe with the beheviour of Cnyphausen and Grumblow, and no doubt tho twar was advised by the prince of Anhalt through his creature Mardefeld. Grumblow, he said, had not so far responded to his advances, but he was certainly at utter varianos with the prince, with whom none of the ministers seemed to side. 
queen of Prussia counselled Du Bourgay to invite the king to dinner at the first opportunity (he was again away at Wusterhausen), and in the meantime 'to use all the art and labour I can to get a good footing in Messieurs Ilgen's and Cniphausen's favour and confidence as the most effectual means to enable me to answer the Queen's desire' ${ }^{87}$ Shortly he was able to send word of orders going to Mardefeld to do all he could to further the reconciliation. 88

And now surprising and pleasurable news had been received at Paris from Campredon. From conferences with Osterman and Chancellor Golovkin he drew the conclusion that the taar desired a reconciliation, would waive his personal 'griefs', and would consent to receive a British minister, if the king of England would promise to work for a settlement in Mecklenburg and withdraw his troops thence and make understood his willingness to join with France and Russia in compensating the duke of Holstein-Gottorp for his loss of Sleswick. ${ }^{89}$ On these points Morville had already written that George I was not absolutely inflexible." Next Campredon reported an interview with Peter the Great himself on the day that he received the instrument of his peaco with Turkey, obtained for him mainly by the efforts of the French ambassador at Constuntinople. Seizing the opportunity to speak of his own negotiation, Campredon was answered that orders would at once be given which would satisfy him. ${ }^{91}$ On receipt of which news Morville wrote:

Vous avez plus fait en un moment de conversation avec leCzar lui-mème, que vous n'auriez pu faire en plusieurs conférences avec ses ministres; aussi faut-il dire, que le succès de l'affaire vous sers dù principalement.a

In Sweden also the ministers communicated to Finch and Colonel Bassewitz, the Hanoveriın minister, overtures from Bestuzhev, with an expression of belief that the tsar might now be prevailed upon to give the simplo declaration which George I roquired, that all past incidents should be forgotten. And now as always, Finch wrote, the king of Sweden expressed himself desirous of serving his majesty to the best of his ability.9 But when these dispatches reached London Swedish mediation was even less acceptable than formerly, for the news from Campredon had anticipated them. A memorandum given to Count de Broglie with copies of them, recalling its former rejection

n Du Bourgay, 30 Auguat, Record Office, Prussis 18.

4 The ane, 5 September.

w Campredon, 22 July, Sbornik, lii. $256 \mathrm{f}$.

- 11 August, ibid. p. 276.

"' Campredon, 1 August, cited by Vandal, Lowis $X V$ a Elisabelh de Russie, pp. 72, 73.

- 31 Angust, Sbornik, bii. 283.

2 Bassowitz, 12 August; Finch, 19 and 28 August and 2 September, all old style, Record Office, Streden 34. 
out of consideration for France with the result that the treaty of February had been concluded, informed him that, while the present turn of affairs created great surprise, the king did not propose to avail himself of the Swedish offers, that he was still resolved to be reconciled with the tsar only through the mediation of France, and that the only answer to be given, one which it was hoped would soon be possible, was that that mediation had already been successful. 4 However, expressions of satisfaction were returned to Stockholm, Finch being instructed to render thanks for the kind offices employed and to use all civility towards Bestuzhev, giving him the ame reason as before for not visiting him, ${ }^{95}$ but assuring him of the king's readiness to receive him as minister once more, so soon as the reconciliation should be effected.9 This, however, was but poor consolation for the rebuff administered, and both the Swedes and Bestuzher were greatly mortified.7?

Campredon's advices having been received in London, Horatio Walpole was enabled to notify the French government that George I

consented to the reconciliation and alliance in the manner proposed by the Czar himself, with such an explanation only relating to the admission of the Dukes of Holstein and Mecklenburg as was necessary to make things plainly understood to preserve the honour and faith of the two Crowns.98

Later he sent word that it was not expected that a British ambassador should be sent to Russia before the tarar's acceptance of the proposed treaty was known, so that he would have nothing to do but to sign it on arrival; "so that the conclusion of this

a 'Ba Majesté espère avec la dernière confience ... qu'après toutes les concesaions qu' Bllo a faites, le Roy tréte-Chrétien la mettre en état do donner la seulo réponco solido et convenable, à sevoir de donner a entendre a la Sudde que es réconcilietion aver le Czar est conclue par la médiation de a Majesté trùb-Chrótienne. La Cour de Suède ne pourre que ee rejouir de voir une si bonne ceuvre amené a se conclusion, et applandir a l'interposition dont le Roy mon Maitre s'est servi pour cet effet. Et cot 6rènement ne pourra manquer d'avoir des conséquences trè-heureuses tant par ropport enx affaires du Nord qu à celles du Sud, et de nous déberasser de toutes les difficultte qui pourroient retarder lo succè des négociations de Cambray' (ungigned draft, 21 september (0.8.), Record Office, Foreign Ministers 4).

* Finch'declined to' orchange visite with Bestuzhev until an a front given by the Latter to Colonel Bassewits was stoned for.

* Townshend to Finch, 22 September and 9 October (0.8.), Record Office, Foreign Entry Book 15.5.

17 Thas Poynts on 28 Uctober (o.s.): "Tho Count Horn and Secretary Höpken had art anough to conceal their rewentment, yot I believe they are hestily piqued at tho neglect shewn them by the Crar as well as Britain, in this affair of a raconcilistion, and I am well informed, that they have already sent positive orders to thair minister at Paris, to insist on boing admittod to a sharo in finishing it.' And o woek later: Bestushev also was greatly mortified at having no hand in the affair. (Rocord Offer, Brieden 35.)

* H. Walpole, 19 September, British Mfuseum, Add. MS. 38740. 
tedious and difficult negotiation seems to have taken a lucky turn.' Also that the intimation of the king's willingness to recognize the tsar's title of emperor and to receive Bestuzhev back in England, as soon as the treaty should be finished, had given great pleasure. ${ }^{p 9}$ It was decided to draw up a formal treaty to be submitted to St. Petersburg. When the draft had been presented in London Newcastle wrote of the king's satisfaction, especially with the articles concerning the two dukes, and ordered.Walpole to express to the French ministers in the strongest manner his sense of obligation, though with the observation that he accepted the terms purely out of regard to France. The dispatch concluded with congratulation 'upon this great work's being brought so near a conclusion, which His $\mathbf{M a}^{\text {ty }}$ cannot but look upon to be as gool as finished', and with the desire that particular thanks should be rendered to Fleury. ${ }^{100}$

The draft treaty was for a defensive alliance between France, Great Britain, and Russia, but provided for the accession of 'tous les rois, princes et états, qui seront mûs du mêne zèle pour le bien de la chrétienté '. Specified for mutual guarantee were the treaties of Utrecht and Baden, of the Hague and London (the Triple and Quadruple Alliances), those concluded by Sweden in 1719-20 with Hanover, Great Britain, and Prussia, and that of Nystad. The tsar's title of emperor was recognized, with the proviso that no new prerogatives or pre-eminence should accrue to him thereby. Other clauses provided for mutual succour, for liberty of commerce, and so on; the term was fixed at fifteen years; and Sweden and Prussia were specially named as powers whose accossion was desirable. The separate and secret articles were three in number. The first stipulated full liberty of election to the crown of Poland by the republic, the second engaged the kings of France and England to use their best offices in favour of the duke of Mecklenburg-Schwerin, out of regard to the taar, and the third obliged them to do their best to procure for the duke of Holstein-Gottorp, to whom the tsar destined one of his daughters to wife, a proper indemnity for Sleswick, though without derogating from the guarantees which they had given to Denmark.

With the draft went to St. Petersburg dispatches from Louis XV and from Morville discussing the articles in detail, and new full powers for Campredon, in which the tsar was recognized as emperor. Morville wrote :

Je suis persuadé, qu'il ne naîtra aucun obstacle au succès de la négociation, et que les premières nouvelles, que l'on reçevra de vous, seront la certitude de la signature de l'alliance. ${ }^{101}$

- The same, 3 and 6 October, ibid.

10 Nowcastlo to H. Walpole, 26 September (o.s.), ibid.

101 The whole under dato 16 October, Sbornik, lii. 295-321. Morville promised the 


\section{Horatio Walpole for his part expressed himself}

very sensible of the influence that this great work, when it comes to be publickly known, will have upon the affairs of Europe, and what an eclat it will give for his Majesty's honour and interest both at home and abroad. ${ }^{102}$

\section{And Townshend wrote to Poyntz :}

As the scene of affairs is intirely changed with relation to the Czar since you left this place, the $K$. having all the reason in the world to think his reconriliation with that prince as good as concluded, you will not enter into any of the particular private instructions given you till you hear further from ine, but will content your self with carrying your self as easily and civilly as you can to everybody, without giving any person or party any occasion of offence. ${ }^{103}$

The progress of the affair was well looked upon at Berlin. When Wallenrodt expressed himself unable to understand the haughty attitude outwardly maintained by the British court towards the tsar, while he was certain that at heart it would gladly be reconciled with him, he was answered that he need not trouble himself thereat, the king of Prussia being quite contented that the affair was in such good train, even though he had no hand in it, and thinking that an alliance between Great Britain, France, and Russia, which he himself would gladly join, would excite great attention throughout Europe. ${ }^{104}$ In further dispatches, after reporting the attention given to the effair by the Austrian and Saxon envoys in London and the sending of the draft treaty to Russia, Wallenrodt opined that France could not have succeeded so far, had sho not been so instrumental in procuring for the tsar his peace with Turkey ; that her success would influence the congress of Cambray and bring the emperor ${ }^{106}$ to reason; that she desired no war, having abandoned her former principle of conquest; and that the accomplishment of the negotiation would have good results for Prussia, as a guarantee for Juliers and Berg could be obtained: in fact, the new alliance might be regarded as founded on the treaty of Charlottenburg. But the Hanoverian ministers, he said, disposed to a good understanding with the emperor and jealous of Prussia, viewed the proceedings malevolently, and Bernstorff in particular, since he would no longer be able to play the master

immedisto dispatch of 40,000 crowns for gratifications to persons at court, and did not doubt that Georgo I would pey the 80,000 already arranged for.

iv 14 October, Britigh Museum, Add. MS. 32741.

10 $\theta$ October (0.8), Record Offico, Swoden 35.

is Wallenrodt, 28 September, and rescript to him of 10 October, Steatsarchiv, Berlin. Mardefeld on 24 October was ordered again to press the said alliance with the toser and his ministers (ibid.).

low "Welcher sich gleichsam von allen Ecken belagert siehot. 
in Mecklenburg. And the king appeared still to be in doubt of the tarar's sincerity. ${ }^{100}$ He was instructed in reply to watch carefully what went on, in order that Prussia might not be behindhand in guarding her own interests, and to deny absolutely and at every opportunity that Prussia had any engagements with any one, particularly with the tsar, excepting in regard to the Courland marriage-treaty, wherein Russian aid had been enlisted in order to defeat Polish intrigue; any assertion to the contrary was the false invention of the Austrian and Polish courts. And since to accede to the treaty subsequently would bring but little advantage, he must try to get Prussia included in it as a principal party. Chambrier was ordered to say to Morville : que j'étois véritablement charmé de le voir dans de si bons sentiments par rapport à une étroite liaison entre la France, l'Angleterre, le Tzaar et noy. Que j'y répondrois de mon côté avec toute la sincérité imaginable, et contribuerois tout ce qui dépend roit de moy, pour un si grand ouvrage. ${ }^{107}$

These instructions were sent in full belief that the alliance would be made. Du Bourgay had written on 21 October : ' I am now positively assured by the ministers here, that the reconciliation between our Court, and the Czar, is concluded,' on the tsar's part with great cheerfulness and good resolve for the future. ${ }^{108}$ And later :

Whilst I was in his Majesties closet, he sent for Count Golowkin, and desired we should embrace and congratulate each other in his presence, on the happy reconciliation of our Courts, which we did accordingly very heartily. On which his prussian Majesty expressed both in his countenance and words, all the joy and satisfaction imaginable. Among other things his Majesty said, that the Protestant interest might now truly be sayd to be free from any insults of its adversaries, and that he could declare with pleasure, he had contributed all in his power to this good work, which he had at heart for these two years past. 100

Public report attributed the supposed success to the king of Prussia's influence with the tsar, and even declared that at this interview the ratification of the treaty was actually presented by the British envoy. 110

Of course all this roused the greatest disquietude at Copenhagen. Du Bourgay on 5 September had cited Lövenörn's

106 Wallenrodt, 24 October to 14 November, ibid.

in Rescripts to Wallenrodt, 31 October and 28 November, and to Chambrier, 14 November, ibid.

100 'As be is assured, that it is the onely method, to gain credit and influenoe in the affairs of Europe : espectaly in his intended treaties of commerce with Franece and Bpain' (Beoord Office, Prusesin 18).

20. The oame, 7 Novomber.

110 Lettres historiques, Ixvi. 319 ; Wich from Hamburg 16 and 22 November, Rocord Office, Hamburg 41. 
expression of fear that Denmark would have to pay. Shortly afterwards Frederick IV made fresh advances to Russia, personally drawing up instructions to Westphalen at St. Petersburg to endeavour to establish a good understanding with the tsar and with the duke of Holstein-Gottorp. He offered the duke Oldenburg and the right to redeem Delmenhorst, mortgaged to Hanover, in return for the cession of his share of Holstein to Denmark, in case he succeded to the throne of Sweden. And he undertook to recognize the tsar's imperial title, if he would give up his claim to exemption from the Sound tolls. To help the negotiation, Westphalen was empowered to offer to Campredon and to Bassewitz, the duke 's minister, a real ' reconnaissance '.' But nothing came of this. and Denish fears increased. Wich at Hamburg bears witness to this. saying that the Danish minister at Paris had been ordered to find out what he could. ${ }^{112}$ And Glenorchy wrote on 2 December :

I find the Court is alarm'd at the reconciliation between his Majesty and the Czar, and tho the Ministers have never spoken to me on that subject, I know that the Grand Chuncelier has said it would be to the prejudice of Denmark. ${ }^{113}$

Townshend advised him on 12 January (o.8.) 1725 :

Monsr. de Söhlenthal is very uneasy here and continually teizing me about the business of His Maty' reconciliation with the Czar, and tho I bave told him fairly how careful His Majty has been of his engagemente with His Master, . . . yet I find he is still incredulous. . . His Majesty has been so sollicitous in the progress of this affair to preserve and secure the guaranty given to the king of Denmark both by himself and France, that be thinks it the best thing that can happen for the advantage of that Kingdom that the reconciliation should go on and succeed in the method it is put. 114

But it was not succeeding. Sanguine as were the hopes expressed, they were doomed to disappointment. Only after recoipt of the draft treaty could ('ampredon obtain an interview with the Russian ministers even to discuss preliminaries. In interpreting as he did Peter the Great's outburst of confidence in July he must have been mistaken, for immediately afterwards Peter informed Prince Boris Kurakin, now once more accredited to Paris, ${ }^{115}$ that the reply to his exposition of French policy (of $13 \mathrm{March}^{116}$ ) must be deferred until it was seen whether there

i1 Holm, pp. 85-7.

"' 6 October, Rocord Office, Hambury 41. The minister in queetion, Wederkop, whes Wich' brother-in-law.

is Rocord Offico, Donmark 47 . is Record Office, Fareign Entry Book 6.

is He had returned thither at the beginning of Jenuary, and later received formsl credentials of date 13 Fobrusery (0.8.), Kreatin Archives, ii. 168.

ue Ibid. iii. 243, cf. ante, xxvi. 308. 
was not some change of view at the French court, for written obligations would not be entered into with England. ${ }^{117}$ In any case Peter's attention was almost wholly taken up by his domestic affairs, particularly by the Mons scandal, which so gravely affected him, while the illness which was soon to prove fatal was increasing upon him. Moreover, the clauses concerning his two client dukes were not to his content, and he had lately received a fresh rebuff to his great ambition, to marry his daughter Elizabeth into the royal house of France.

In the first week of December took place the betrothal of the duke of Holstein-Gottorp to the eldest tsarevna Anne, and Campredon had word of a secret treaty attaching thereto, which guaranteed to the duke the succession in Sweden, promised either to recover for him his lost estates or to indemnify him by others yielding an equal revenue, and engaged the succession in Russia for whichever of his sons should be most fit. ${ }^{18}$ And though on 16 December he could still write, after an interview with Count Tolstoi, 'Je ne désespère point ... que ln négociation n'ait un hcureux succès,' he had next to report that excuses were still made, and on 9 January Osterman's definite statement that, while the tsar still wished to ally himself with France, he would only admit the king of England subsequently, nor form alliance with him previously to a reconciliation. He concluded : 'il est certain que le Czar ne se serait point porté aux avences, qu'il a faites, touchant sa réconciliation, s'il n'y avait pas trouvé son avantage, le seul motif, qui le détermine.' ${ }^{119}$

Meanwhile Morville could not bring himself to believe the truth of Campredon's accounts, ${ }^{120}$ and Horatio Walpole consoled himself by writing: 'I must own I do not like the appearances of this affair at present, ... but at all events we may depend upon it, that this Court will not enter into any alliance with the Czar exclusive of us.' ${ }^{122}$ Yet Du Bourgay learnt at Berlin that 'I might depend the treaty was in so great forwardness that it would soone be perfected, in the manner the french would have it, and to the King's entire satisfaction ', ${ }^{122}$ and even at the

11 Ibid. 1. 34.

11s Ibid. pp. 366, 378, 385.

- 'Je ne puis pas craire, qu'après que le Czar a consenté da admettre un ambassar deur d'Angleterro, qu'il a obtenu du roi do lo Grendo-Bretagno l'admiscion do $S^{r}$ Bestongeff ot aur les interts dee duch de Holstein et de Mecklembourg uno etipuletion aussi étendue, que les engagements sntérianres du roi d'Angleterse ont piu lai promettro, il veuille se retracter, renoncer a tant d'avantages differents et compromettre lo nom du roi . . F Felaircisez, s'il vous plait, co mystìre et motter-moi en btat de sevoir, sur quoi l'on pout compter, lornque l'un voit une veristion si marquto su moment, qu'on a lieu d'esperer une fin prochaine, qui on effet n'eot suspondae par rien de la part du roi et du roi d'Angleterre' (Morville to Cumpredon, 7 Deoember, Sbornik, lii. 355).

iv 26 December, British Museum, Add. Mr. 32741.

186 January 1725, Record Uffice, Prussia 18. 
end of January Walpole reported Morville to say that ' he did not find, by anything that Mr. ('ampredon had wrote, the least reason to apprehend that this affair would miscarry', and the duke of Bourbon to think that 'the dilatoriness of the Czar' was rather due to preoccupation by his domestic concerns 'than out of any backwardness or aversion to the thing itself '. ${ }^{123}$

On 1 February Bourbon expressed to Campredon his extreme impatience to know the truth, seeing that it was necessary to take, one way or another, steps to secure the tranquillity of the north. ${ }^{124}$ Seven days later Peter the Great died. His widow and successor was credited with a hatred of Hanover even greater than his ${ }^{125}$ and with a special affection for the duke of Holstein-Gottorp. And so, on receipt of the news of her successful usurpation, Campredon, on request from London, was ordered to suspend negotiations until he should be further instructed.

Nor did greater success attend another consequence of the new situation created in September, the resumption of negotiations for the accession of France to the treaty of Charlottenburg. Morville, his chief objection being removed, was now found to favour the proposal, but Fleury, strangely, to oppose it. ${ }^{128}$ To meet his objections, presumably, the idea of a simple accession was given up and a new treaty was drafted, modelled on that of Charlottenburg but containing alterations suited to France becoming a party. ${ }^{197}$ There was a strong desire at Paris, Walpole wrote, for taking Prussia 'into a strict union', but it was thought that thearticle regarding Juliers and Berg would prove a stumblingblock in the way of the accession of the Dutch. ${ }^{128}$ Newcastle,

m 27 and 30 January, British Mluseum, Add. MS. 32742.

the Sbornik, lii. 416.

iw 'La Czarine ayant été personnellement traitée aveo pou d'égerds, lorsqu'elle pasa par l'électorat de Hanovre, alle aura conservé contrele roi de le Grande-Bretegne un mécontentement plus difficile a surmonter, que n'a voit été celui du Czar, dont l'éloignoment était contrebaloncé par des projets et des vaes, que la Czarine ne serait peut-etre pas en volonté, ni en pouroir, de pourvilivre' (Bourbon to Campredon, 8 Jarch, ibid. 451).

2* H. Walpole, 4 November, Add. Ms. 32741. He could only conjecture Fleary's motives, suggesting that, as a bigoted cathulic, he might object to Juliers and Berg falling into the bande of a protestant power. To the duke of Bourbon, who sided with Morville, he ascribed the possible hope of acquiring, as the price of his assent, the sovereignty of Nenchatel. Later (24 February 1725) be retracted bis conjecture about kloury : "I must do him this justioe to say, that in the many conferences I have had with him, le has often made this distinction, of being a thorough Roman Catholick, and for supporting that raligion in the highest degree in France, and at the amo time a good Prutcatant in the alliances to be made by this Crown abroad '(Add. MS. 32742).

in For inrtance, " the omitting to mention the protestant religion in the presmble, and the inerting of the necossary clausey with ralation to the cases in which $\mathrm{His}$ Majesty and the King of Pruain as Princes of the Empire are, or are not to pay their contingent, should a war happon between the Empire and France.'

in H. Walpole, 14 November, Add. MIS. 32741. He had previously suggested (4 Noveuber) that the Dutch might be satisfied by an agreement on the Orange sucoession aud by obtaining the upper quarter of Guelders and the Elector Palatino's seignory of 'Raveteyn' (Ravenstein). 
for his part, intimated the king's pleasure at seeing a disposition on the part of France to come into the treaty, while not thinking it so necessary as formerly ; on the very delicate question of the succession to Juliers and Berg he was loth to enter into further engagements, and did not think that the king of Prussia would have cause to be disobliged if Walpole answered, if approached on the subject in form, that it was not considered advisable at this juncture to alter their nature; only he must beware of giving any explanations which might not be very agreeable to the king of Prussia. ${ }^{129}$ The draft having been presented by Count de Broglie in London, Newcastle wrote that George I entirely approved of it, and only desired the insertion among the treaties to be guaranteed of that of 1720 between Great Britain and Sweden, to which, though objected to in the case of the proposed Russian treaty. ' as containing some engagements which, thô at an end, might have been disagreeable' to the tsar, there was no such objection in this case. ${ }^{130}$ And he desired Walpole to express to the duke of Bourbon and the other French ministers

in the atrongest manner the sense His Mujty has of this new mark of their zeal for strengthening and improving the union and harmony between the two Crowns, by France's becoming a party to a treaty of such inportance to the preservation of the publick tranquillity both in the North and South. ${ }^{131}$

The negotiations went on during the winter, but not with the easy course expected, Prussia advancing demands reasonable enough from her point of view but from the other inadmissible. 'They were suspended when at the beginning of March 1725 news arrived not only of the death of Peter the Great but also of the secret work which Ripperda was doing at Vienne. on behalf of Spain, behind the backs of the mediators at Cambray. How Great Britain, France, and Prussia eventually entered into alliance under a political situation greatly altered belongs to the story of the treaty of Hanover of the following September.

.J. F. ('HANCr.

120 Newcastle to H. Walpole, 2 November (0.8.), ibid.

100 To meet the difficulty of the reference to the protestant religion in this treaty, it was proposed to add to the mention of it the wordh, "Ba Majesté Très Chretienne se remettant en tout co qui regarde la Religion au Traité de Westphalie.'

wh Nowcestle to H. Walpole, 12 Novembur (o.s.), ibid. 